Geology, Geophysics \& Environment • 2012 • Vol. 38 • No. 4 • 369-393

http://dx.doi.org/10.7494/geol.2012.38.4.369

\title{
HYDROTHERMAL FLUIDS INFLUENCE ON THE THERMAL EVOLUTION OF THE STEPHANIAN SEQUENCE, THE SABERO COALFIELD (NW SPAIN)
}

\author{
Dariusz BOTOR \\ AGH University of Science and Technology, Faculty of Geology, Geophysics \\ and Environmental Protection, Department of Economic and Mining Geology; \\ al. Mickiewicza 30, 30-059 Krakow, Poland; \\ e-mail: botor@agh.edu.pl
}

\begin{abstract}
In the present study, the thermal history of the Late Carboniferous (Stephanian) coal-bearing sediments of the Sabero Coalfield has been reconstructed in order to elucidate coal rank. The Sabero Coalfield is located in a small intramontane coal-bearing basin along the Sabero-Gordón fault zone, one of the major E-W trending strike-slip fault systems of the southern part of the Cantabrian Zone (NW Spain). The total thickness of the Stephanian succession is in excess of 2,000 m, and is composed of siliclastic rocks and intercalated coal seams with tonsteins. Mean vitrinite reflectance values in the Stephanian rocks in the Sabero Coalfield are in the range from 0.61 to $3.14 \% \mathrm{Rr}$, but most values are in the range from 0.8 to $1.5 \% \mathrm{Rr}$ (based on 84 samples). Average vitrinite reflectance gradient is high $(0.73 \% \mathrm{Rr} / \mathrm{km})$, which suggests high value of average paleogeothermal gradient $\left(52^{\circ} \mathrm{C} / \mathrm{km}\right)$. The maximum paleotemperatures calculated from vitrinite reflectance values for the Stephanian rocks range between $89^{\circ} \mathrm{C}$ (top of the Stephanian) and $195^{\circ} \mathrm{C}$ (bottom of the Stephanian). Coalification of the organic matter in the Stephanian rocks was achieved in the Early Permian, and was most likely related to several almost simultaneous related to magmatic and hydrothermal activity during high subsidence period in the pull-apart basin. The primary, burial-related maturity pattern, was probably slightly overprinted by fluid migration event, which is supposed to have occurred in Early Permian time.
\end{abstract}

Key words: Spain, Cantabrian Mountains, Sabero Coalfield, Carboniferous, pull-apart basin, coalification, thermal history, maturity modelling, vitrinite reflectance, eroded overburden

\section{INTRODUCTION}

Most of the Spanish coal deposits are located in the Cantabrian Mountains containing $\sim 70 \%$ of the total coal resources, and $95 \%$ of the anthracitic and bituminous resources of the country (e.g. Colmenero \& Prado 1993, Colmenero et al. 2008). Despite this, few studies 
were published on the origin of these deposits. Colemenero \& Prado (1993) were the first authors to publish a map of coal rank of the area based on the volatile matter of coals. Piedad-Sánchez et al. (2004a, 2004b) studied the petrography and thermal evolution of coals in the Central Asturian coalfield (Westphalian age), while Frings et al. (2004) carried out a study of thermal history in the Cinera-Matallana Coalfield (Stephanian age), which is located only $14 \mathrm{~km}$ west of the Sabero Coalfield. Recently, Colmenero et al. (2008) published an overview of the coal basins in the Cantabrian Mountains covering geological and coal petrological aspects.

There is a long tradition of using the patterns of coalification to reconstruct the thermal history of sedimentary basins including maturity modelling (e.g. Teichmuller 1987a, b, Yalcin et al. 1997 and references therein). The modelling procedure typically starts with a conceptual model, based on recognized geological evolution of a given basin, such as deposition, non-deposition, and erosion. The validity of such models depends on the quality of input data (Noth et al. 2002). By far the most widely used data for calibration of the temperature history are vitrinite reflectance values, which can be compared with modelled vitrinite reflectance values, such as those calculated by the kinetic EASY \%Ro method (Sweeney \& Burnham 1990), as in this paper. Another approach is based on empirical studies (e.g. Barker \& Pawlewicz 1994), which has also been used in this work. In the present study, the thermal history of the Late Carboniferous (Stephanian) coal-bearing sediments of the Sabero Coalfield was reconstructed in order to elucidate coal rank, in which hydrothermal activity could be an important factor (e.g. Hower \& Gayer 2002).

\section{GEOLOGICAL SETTING}

The Cantabrian Zone (CZ) represents the foreland of the Iberian Massif. The present structure and relief resulted, however, from the superposition of the Variscan and Alpine orogenesis and intervening extensional tectonics. Precambrian rocks of the Narcea Antiform separate the CZ from the more internal areas of the orogen (e.g. Bastida et al. 1999). Two stratigraphic domains are recognised in the CZ: the Asturian-Leonese and the Palentine. The former comprises the following thrust units: Somiedo-Correcilla, Sobia-Bodón, Aramo, Central Coal Basin, Ponga and Picos de Europa. The latter corresponds to the PisuergaCarrión Unit (Pérez-Estaún et al. 1988). The Cantabrian zone consists of a Precambrian basement covered by Paleozoic sediments. These underwent intense thin-skinned tectonics, diagenetic to epizonal thermal events, and several episodes of fluid flow (Aller et al. 2005).

The Sabero Coalfield is located in a small ( 12-16 km long and 3-4 km wide) intramontane coal-bearing basin along the Sabero-Gordón fault zone, one of the major E-W trending strike-slip fault systems of the southern part of the Cantabrian Zone (Fig. 1). This area constitutes the external zone of the Variscan orogenic belt in the NW part of the Iberian Peninsula. Two different successions can be recognized with relation to the Variscan deformation: one pre-orogenic and one syn-orogenic. The pre-orogenic sequence is formed by the Lower Paleozoic siliciclastic rocks and the Devonian carbonate and clastic formations. 


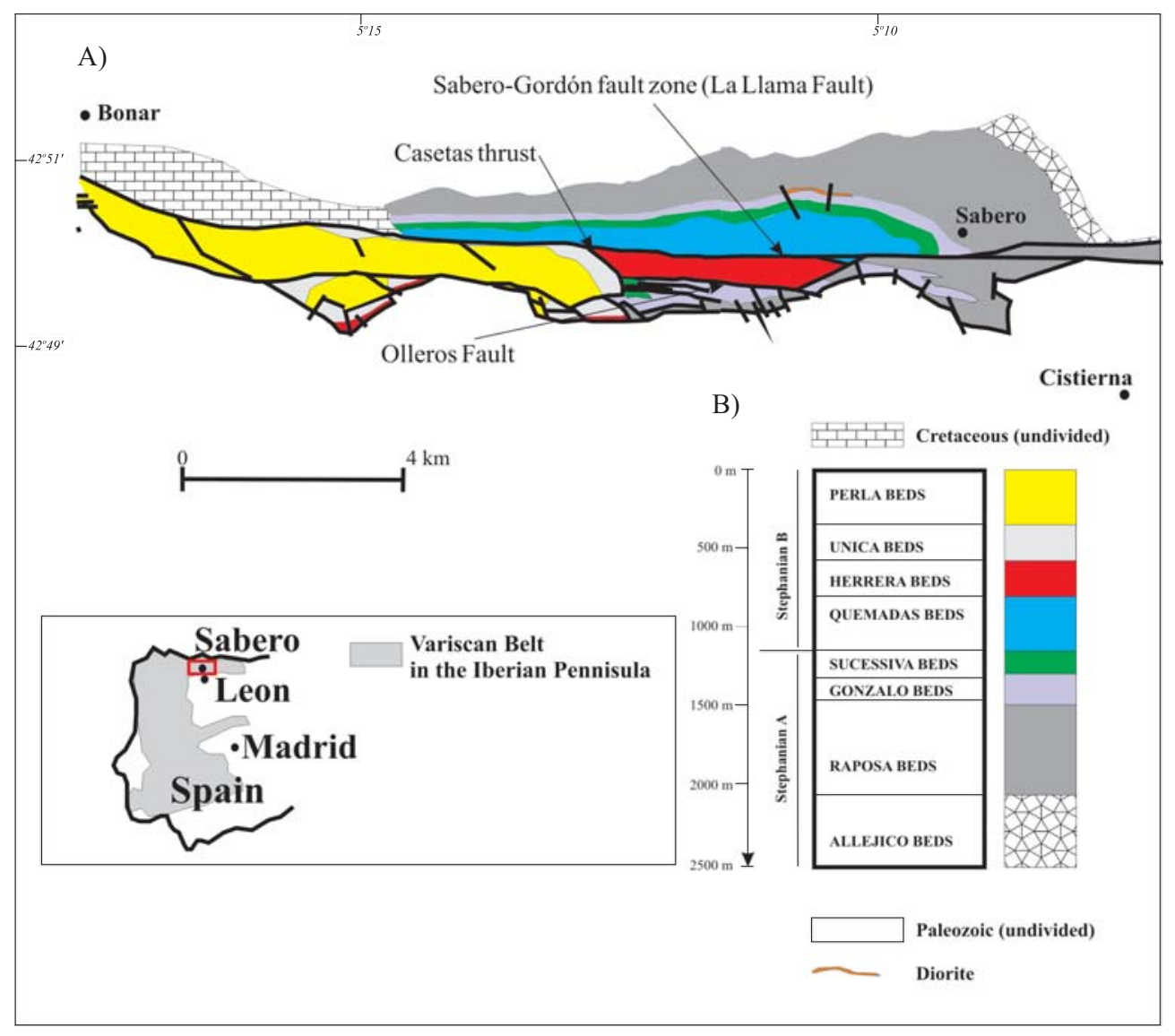

Fig. 1. Geological sketch map of the Sabero Coalfield without Quaternary (A) and sedimentary sequence showing maximum thickness of the coal-bearing formations within basin (B) (data modified from Rodriguez-Fernandez et al. 1978, 1979, 1988, Knight 1983, Pérez-Estaún et al. 1988, Knight et al. 2000)

The synorogenic Carboniferous pile is interpreted as a foreland basin sequence (Julivert 1971, Marcos \& Pulgar 1982). Both successions were complexly folded and thrust under a thin-skinned tectonic regime between the Westphalian B and Stephanian times (Julivert 1971, Bastida et al. 1999). The Sabero Coalfield contains the Stephanian A and B coalbearing clastic sequences (Fig. 1) rest uncomfortably over the older Paleozoic rocks and were deposited in a small pull-apart basin (Reading 1975, Heward \& Reading 1980) which was strongly faulted, particularly in its southern limb, during the latest phases of the Variscan orogeny (Knight 1983, Knight et al. 2000). The Stephanian A strata contain about 20 coal seams and coal intercalations, thickness of which ranges from 0.3 to 2.0 meters. The Stephanian B strata contain over 50 coal seams and coal intercalations, with thickness ranging from 0.1 to 3.5 meters. The succession reaches maximum thickness $\sim 2,500 \mathrm{~m}$, 
and is composed of conglomerates, sandstones, shales and siltstones, with intercalated coal seams with tonsteins (Heward 1978, Knight 1983, Wagner \& Winkler-Prins 1985, Colmenero \& Prado 1993, Knight et al. 2000, Botor 2005, Colmenero et al. 2008). Small sills and dikes of diorite or more basic composition frequently penetrate the coal seams. Pyroclastic horizons are common (Knight et al. 2000). Following sedimentation of the Stephanian succession there was a long period of non-deposition and erosion until the Cretaceous. During the Albian to Santonian, diachronous deposition of a 150 to $800 \mathrm{~m}$ thick sediments occurred in the area (Evers 1967). Following the Alpine orogeny, which led to complex folding and reactivation of the Variscan faults along the southern boundary of the Cantabrian Zone (Alonso et al. 1995), erosion dominated and still persists today.

In most areas of the Cantabrian Zone (CZ), diagenetic conditions were dominant. However, low-grade metamorphism developed locally (Aller \& Brime 1985, Aller 1986, Raven \& Van der Pluijm 1986, Colmenero \& Prado 1993, García-López et al. 1997, 1999, Bastida et al. 1999, Brime et al. 2001, Frings et al. 2004). Two distinct metamorphic events affected the CZ. The first event resulted from peak burial in the Westphalian and superimposed regional Variscan tectonic subsidence. It is exclusively manifested in the westernmost CZ. Metamorphic grade (up to epizone) is higher in older rocks. It developed previously and/or during the early stages of thrusting, with little of post-thrusting metamorphism resulting from tectonic loading (Raven \& Van der Pluijm 1986, García-López et al. 1997, 1999, Bastida et al. 1999, Brime et al. 2001). The second event is late- to post-Variscan and is thought to be Late Stephanian-Early Permian in age (Aller 1986, García-López et al. 1999, Brime et al. 2001). It consists of two different processes. One is related to extensional tectonics (Aller 1986, Colmenero \& Prado 1993, García-López et al. 1999), which developed as mostly anchizonal to epizonal conditions. The other developed contact aureoles between post-Variscan granitoids and the intruded rocks. These two processes are genetically interrelated and frequently act jointly, with contact metamorphism representing the final stage of the process.

In the $\mathrm{CZ}$ the Variscan granitoid stocks are well-known. They have a tonalite-granodiorite-monzogranite composition and appear along with mafic to intermediate dykes (Fernández-Suárez et al. 2000). The granitoids formed by melting of the lower crust with varying involvement of mantle-derived melts. The mafic to intermediate dykes originated as mantle melts with some crustal contamination (Galán \& Suárez 1989, Galán et al. 1996). The largest granitoids are in the Pisuerga-Carrión Unit. In the westernmost CZ granodioritic to gabbroic intrusions are also known, which are mostly located along deep, late-Variscan faults of considerable lateral extension (Julivert 1971, Corretgé \& Suárez 1990, Gallastegui et al. 1990). In the Permian, an important alkaline volcanism also developed (Corretgé \& Suárez 1990).

Most plutonic intrusions in the Cantabrian and northern Central Iberian Zones invaded between approximately 295 and 285 Ma, indicating post-tectonic extension (Fernández-Suárez et al. 2000). This post-tectonic magmatic event began a few million years earlier in 
the most internal zones of the Variscan Belt (Dallmeyer et al. 1997). Fernández-Suárez et al. (2000) and Gutiérrez-Alonso et al. (2004) propose that delamination of the lithosphere was a triggering mechanism for the voluminous, orogen-wide, magmatic event. The final décollement of the crust and lithospheric mantle is evidenced by orogen scale lower crustal melting, widespread magmatism, fluid flow and coeval mineralization (Gasparrini et al. 2003, Aller et al. 2005). The delamination may have began between 320 and 310 Ma under the Central Iberian Zone culminating between 300 and 290 Ma beneath the entire belt (Fernández-Suárez et al. 2000, Gutiérrez-Alonso et al. 2004). The Variscan deformation lasted to about 290 Ma (Dallmeyer et al. 1997, Martínez-Catalán et al. 1997), with the final, extensional collapse phase of the Variscan orogen having taken place during Stephanian B-C into the Permian across much of Iberia. Basin development was coeval with high heat flow, granitic and monzogranitic magmatism, uplift and extension, creating intramontane continental basins along all of Iberia's margins, possibly in conjunction with décollements along former thrust planes (López-Gómez et al. 2002). In the Cantabrian Mountains several outcrops of dioritic dykes and sills intrude, and are folded along with Stephanian sediments of the Cińera-Matallana Coalfield (Allyón et al. 2003). Although these rocks are not directly dated, the associated magmatic activity and ore deposits within the Cantabrian Zone are reported to be of Lower Permian age, likely between 293 to 262 Ma (Corretgé \& Suárez 1990, Crespo et al. 2000). Denudation eliminated most Stephanian basins in the Iberian Ranges and along the southern margin of Iberia.

Several hundreds shows of mineralisation are known in the CZ. Most of them are fault related and hosted in Carboniferous rocks. The most frequent deposit types are:

- Cu-Co-Ni. These deposits are mostly found in the western CZ and hosted by dolomitised Carboniferous carbonates (Fernández et al. 1985, Paniagua et al. 1995). Less frequently, they are hosted in the Carboniferous sediments near granodioritic to gabbroic intrusions (Loredo \& García-Iglesias 1988, Cepedál et al. 1998).

- Pb-Zn-Ba. These deposits are mainly found in dolomitised Carboniferous carbonates of the Picos de Europa Unit (Gómez-Fernández et al. 2000).

- As-Sb-Au near intermediate to basic dykes (Paniagua et al. 1996, Crespo et al. 2000). Sometimes, they are hosted in basic igneous rocks close to major faults (Gutiérrez et al. 1988, Loredo \& García-Iglesias 1988).

- Talc deposits are hosted in dolomitised Carboniferous carbonates of the eastern CZ (Tornos \& Spiro 2000).

The major metallogenic feature of the southern $\mathrm{CZ}$ is the abundance of hydrothermal mineralization related to regional fractures, such as the León, Tarna, Cofińal, Polentinos and Ventaniella faults (Heward \& Reading 1980, Luque et al. 1990). These deposits occur as veins or breccias in dolomitised carbonates (e.g. Spiro et al. 1995, Paniagua et al. 1996). Mineralization took place during the late Variscan (299-260 Ma) times, and was associated with an extensional stress regime with fluid temperatures of $100-300^{\circ} \mathrm{C}$ (e.g. Ayllon et al. 2003, Gasparrini et al. 2003). 


\section{SAMPLES AND METHODS}

Mean random vitrinite reflectance ( $\mathrm{Rr}$ ) was measured on coal samples and dispersed organic matter in samples of shales and siltstones collected from outcrops of the Sabero sequence. In addition, samples of coal material close to the tonstein horizons (from surface and underground outcrops) well known in this basin were included (Knight et al. 2000, Botor 2005). The reflectance measurements (\% Rr) were carried out on polished grain sections using an Axioskop-Opton microscope in reflected white light mode, using (50x) oil immersion objective, following usual ISO procedures (ISO 7404-5, 1994). Even though the outcrops were used for sampling, oxidized samples (or regions within samples) were eliminated and only the non-oxidized internal parts of the rocks were measured for vitrinite reflectance.

Vitrinite reflectance data were used for calibration of the maturity modeling of one idealized (simplified) pseudo-well. The lithology and stratigraphical thickness are based on: Manjon-Rubio et al. 1982, Colmenero-Navarro et al. 1982, Truyols et al. 1984, Rodriguez-Fernandez et al. 1978, 1979, 1988, 1990, Pérez-Estaún et al. 1988, Knight 1983, Knight et al. 2000. The applied methodology has been explained in detail by Oncken (1982) and Noth et al. (2002). Simulations of paleo-heat flow and burial history were performed by PetroMod 1-D numerical modelling software of IES GmbH (Aachen, Germany). For calibration of the temperature history, the kinetic EASY \% Ro method (Sweeney \& Burnham 1990) was applied. Modelling was carried out by varying the paleo-heat flow and erosion values until the best-fit was attained between measured and calculated vitrinite reflectance data. Additionally, the approach of Barker \& Pawlewicz (1994) was used to calculate paleotemperatures and gradients as this method seems to be the most appropriate in the Cantabrian Zone (see Frings et al. 2004).

\section{RESULTS AND DISCUSSION}

Results of the vitrinite reflectance measurements of the samples from the Sabero coal-field are given in the Table 1 and in the Figure 2. 1-D thermal modeling was performed using a basic input data given in a Tables 1-2. In Figures 3-4 are shown calcu-lations of $\mathrm{Rr}$ gradients, geothermal gradients and amounts of the removed overburden. The results of numerical modelling of thermal maturity are given in Figures 5-8. Single sample, which has a value of $3.14 \% \mathrm{Rr}$ is located close to a Permian igneous dyke from the northern part of the Sabero Coalfield. In few samples cokes are also found (Botor 2009), and these were excluded from the data set used for calculations and modeling of the regional thermal evolution. Most values of vitrinite reflectance of the Stephanian sedimentary sequence are in the range from 0.8 to $1.5 \%$, with median value $1.15 \% \mathrm{Rr}$ (Tab. 1, Fig. 2). Recent investigations of the tonstein mineralogy (Knight et al. 2000) and illite crystallinity of pelitic rocks and coal rank (Frings 2002) confirm the predominantly diagenetic character of these rocks. Recently Colmenero et al. (2008) reported thermal maturity of the Sabero Coalfield in the range $0.92-1.5 \% \operatorname{Rr}$ (based on 23 samples), a value that corresponds well with the results of this study. 


\section{Table 1}

The vitrinite reflectance values for the Stephanian rocks of the Sabero Coalfield. Maximum thickness of each Stephanian formation is also given. Estimated paleotemperatures are based on Barker \& Pawlewicz method (1994)

\begin{tabular}{|l|c|c|c|c|c|}
\hline \multirow{2}{*}{ Formation } & \multirow{2}{*}{$\begin{array}{c}\text { Maximum } \\
\text { thickness } \\
{[\mathrm{m}]}\end{array}$} & range & $\begin{array}{c}\text { number } \\
\text { of samples }\end{array}$ & average & $\begin{array}{c}\text { Paleotemp. } \\
\text { calculated } \\
{\left[{ }^{\circ} \mathrm{C}\right]}\end{array}$ \\
\cline { 3 - 6 } & 490.0 & $0.71-1.27$ & 9 & 0.99 & 135 \\
\hline Perla & 280.0 & $0.82-1.20$ & 7 & 1.01 & 136 \\
\hline Unica & 300.0 & $0.89-1.40$ & 14 & 1.17 & 148 \\
\hline Herrera & 205.0 & $0.61-1.18$ & 11 & 0.99 & 135 \\
\hline Quemadas & 150.0 & $0.96-1.35$ & 9 & 1.15 & 147 \\
\hline Sucesiva & 140.0 & $0.86-1.23$ & 12 & 1.07 & 141 \\
\hline Gonzalo & 650.0 & $0.81-1.50$ & 18 & 1.07 & 141 \\
\hline Raposa & 300.0 & $1.20-1.85$ & 4 & 1.53 & 170 \\
\hline Alejico & & & & 9 & \\
\hline
\end{tabular}

Table 2

The basic input data used for a maturity modeling

\begin{tabular}{|c|c|c|c|c|c|c|c|c|c|c|}
\hline \multirow{2}{*}{$\begin{array}{c}\text { Formation } \\
\text { name }\end{array}$} & \multicolumn{2}{|c|}{ Depth [m] } & \multirow{2}{*}{$\begin{array}{c}\text { Present } \\
\text { thickness } \\
{[\mathrm{m}]}\end{array}$} & \multirow{2}{*}{$\mid \begin{array}{c}\text { Present } \\
\text { erosion } \\
{[\mathrm{m}]}\end{array}$} & \multicolumn{2}{|c|}{$\begin{array}{c}\text { Deposition } \\
\text { age }[\mathrm{Ma}]\end{array}$} & \multicolumn{2}{|c|}{$\begin{array}{l}\text { Erosion } \\
\text { age }[\mathrm{Ma}]\end{array}$} & \multirow{2}{*}{ Major lithology } & \multirow{2}{*}{$\begin{array}{c}T c \\
\text { at } \\
20^{\circ} \mathrm{C} \\
{[\mathrm{W} / \mathrm{mK}]}\end{array}$} \\
\hline & top & botom & & & from & to & from & to & & \\
\hline Quaternary & 0.0 & 1.0 & 1.0 & - & 1.8 & 0.0 & - & - & SANDsilty & 2.97 \\
\hline Cretac_erod* & 1.0 & 1.0 & 0.0 & 800 & 130.0 & 65.0 & 65 & 2 & SAND\&SHALE & 2.65 \\
\hline Mezo_hiatus & 1.0 & 1.0 & 0.0 & - & 230.0 & 130.0 & - & - & none & - \\
\hline Eroded_C/P* & 1.0 & 1.0 & 0.0 & 1650 & 300.0 & 295.0 & 295 & 230 & SANDsilty & 2.97 \\
\hline Perla & 1.0 & 491.0 & 490.0 & - & 301.0 & 300.0 & - & - & SILTsandy & 2.55 \\
\hline Unica & 491.0 & 771.0 & 280.0 & - & 302.0 & 301.0 & - & - & SANDsilty & 2.97 \\
\hline Herrera & 771.0 & 1071.0 & 300.0 & - & 303.0 & 302.0 & - & - & SANDshaly & 2.78 \\
\hline Quemadas & 1071.0 & 1276.0 & 205.0 & - & 303.9 & 303.0 & - & - & SHALE\&SAND & 2.65 \\
\hline Successiva & 1276.0 & 1426.0 & 150.0 & - & 305.0 & 303.9 & - & - & SHALE\&SAND & 2.65 \\
\hline Gonzalo & 1426.0 & 1566.0 & 140.0 & - & 305.7 & 305.0 & - & - & SHALE\&SAND & 2.65 \\
\hline Raposa & 1566.0 & 2216.0 & 650.0 & - & 306.0 & 305.7 & - & - & SAND\&SHALE & 2.65 \\
\hline Alejico & 2216.0 & 2516.0 & 300.0 & - & 306.5 & 306.0 & - & - & SANDcongl & 2.93 \\
\hline
\end{tabular}

* Different values of the models are given in Figures 5, 6 . $T c-$ thermal conductivity. 


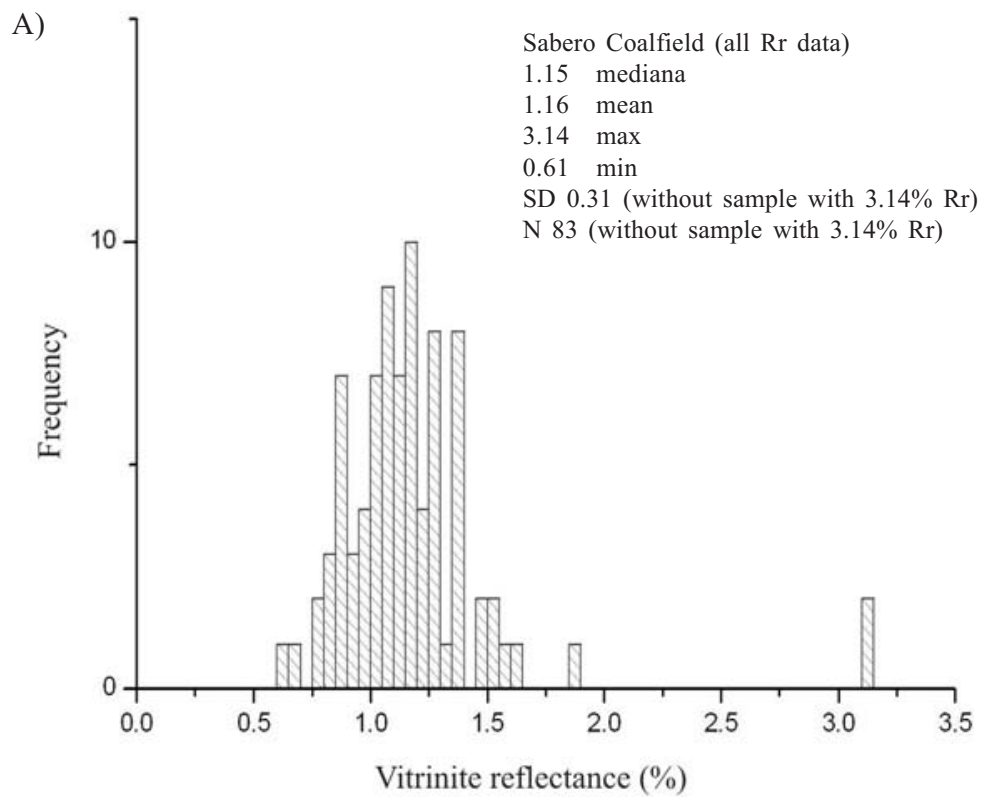

B)

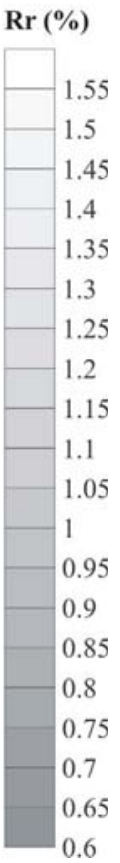

Fig. 2. Distribution of the vitrinite reflectance measurements in the Stephanian rocks of the Sabero Coalfield (A) ( $N$ - total number of samples, $S D$ - standard deviation); spatial distribution of the $\mathrm{Rr}$ on the present-day erosional Stephanian sequence surface (B) 
The spatial distribution of vitrinite reflectance values is complex with different features that must be considered independently. Local maxima of $\mathrm{Rr}$ are visible on the $\mathrm{Rr}$ map in the vicinity of faults (Fig. 2B). However, relation between coalification trend and structural position is not very obvious (Tab. 1, Figs 2B, 3A, 4A). Exact stratigraphical and vertical pattern is difficult to establish because the Stephanian strata are strongly influenced by brittle tectonics. Some parts of the generalized maturation pattern were likely displaced by faults, which can be deduced from the irregular increase of \% Rr (Figs 3A, 4A). Therefore the thermal maturity pattern (Figs 3A, 4A) shows only simplified trend of coalification based on average values established for the mid-formation points.

The vitrinite reflectance gradient is high $(0.73 \% \mathrm{Rr} / \mathrm{km}-$ Fig. $3 \mathrm{~A})$, which suggests rather high paleo-geothermal gradient at the time of maximum burial. However, when attempting a more detailed interpretation of vitrinite reflectance gradient one should take into account that there are several faults dissecting the Sabero Coalfield. For example in the Herrera Formation the vitrinite reflectance gradient is extremely high $(1.03 \% \mathrm{Rr}-\mathrm{Fig}$. $4 \mathrm{~A})$, therefore unusually high $169^{\circ} \mathrm{C} / \mathrm{km}$ paleo-geothermal gradients was calculated (Fig. 4B). Also in the other Stephanian formations of the Sabero Coalfield high paleo-geothermal gradients $\left(112-210^{\circ} \mathrm{C} / \mathrm{km}\right.$ ) were calculated (Botor 2009). The relatively moderate correlation coefficients suggest a discontinuity in the thermal gradients profiles in the Sabero Coalfield. Therefore, the estimated value of $52^{\circ} \mathrm{C} / \mathrm{km}$ (Fig. 3B) should be regarded as average and simplified value. Anyway, this would give extremely high heat flow, which can be explained probably only by hydrothermal activity. Uysal et al. (2000) showed paleo-geothermal gradients in the range of $70-130^{\circ} \mathrm{C} / \mathrm{km}$ in settings influenced by hydrothermal activity. In the Upper Rhine Graben, they generally range between 40 and $90^{\circ} \mathrm{C} / \mathrm{km}$, but locally, can be as high as $120^{\circ} \mathrm{C} / \mathrm{km}$ (Robert 1988).

The validity of the gradient calculations is moderately supported by the sufficiently high correlation coefficients $R^{2}$ of the regression lines (Figs 3-4), indicating peak coalification to have been more or less contemporaneous with peak burial. The scatter of $\% \mathrm{Rr}$ values within each formation is probably also dependent on other factors, like weathering (?) and the likely presence of unre-cognized small-scale faults. In sedimentary basins the increase in vitrinite reflectance is generally considered to be dependent on burial depth, time and the related palaeo-thermal history. The two most important factors are considered to be the palaeogeothermal gradient and the paleo-heat flow (Yalcin et al. 1997).

In this study, the mean palaeo-geothermal gradient calculations and palaeo-heat flow modelling are based on the assumption that the maximum coalification reflects peak burial and peak temperature conditions, which in turn are directly related to the magmatic activities of late-Variscan age. Mendez (1985) concluded that the intrusion of magmas in the CineraMatallana coalfield exerted most pronounced influence on the overall coalification grade with locally restricted anomalies there where the coal-bearing host rocks occur in direct contact with the magmatic material. 


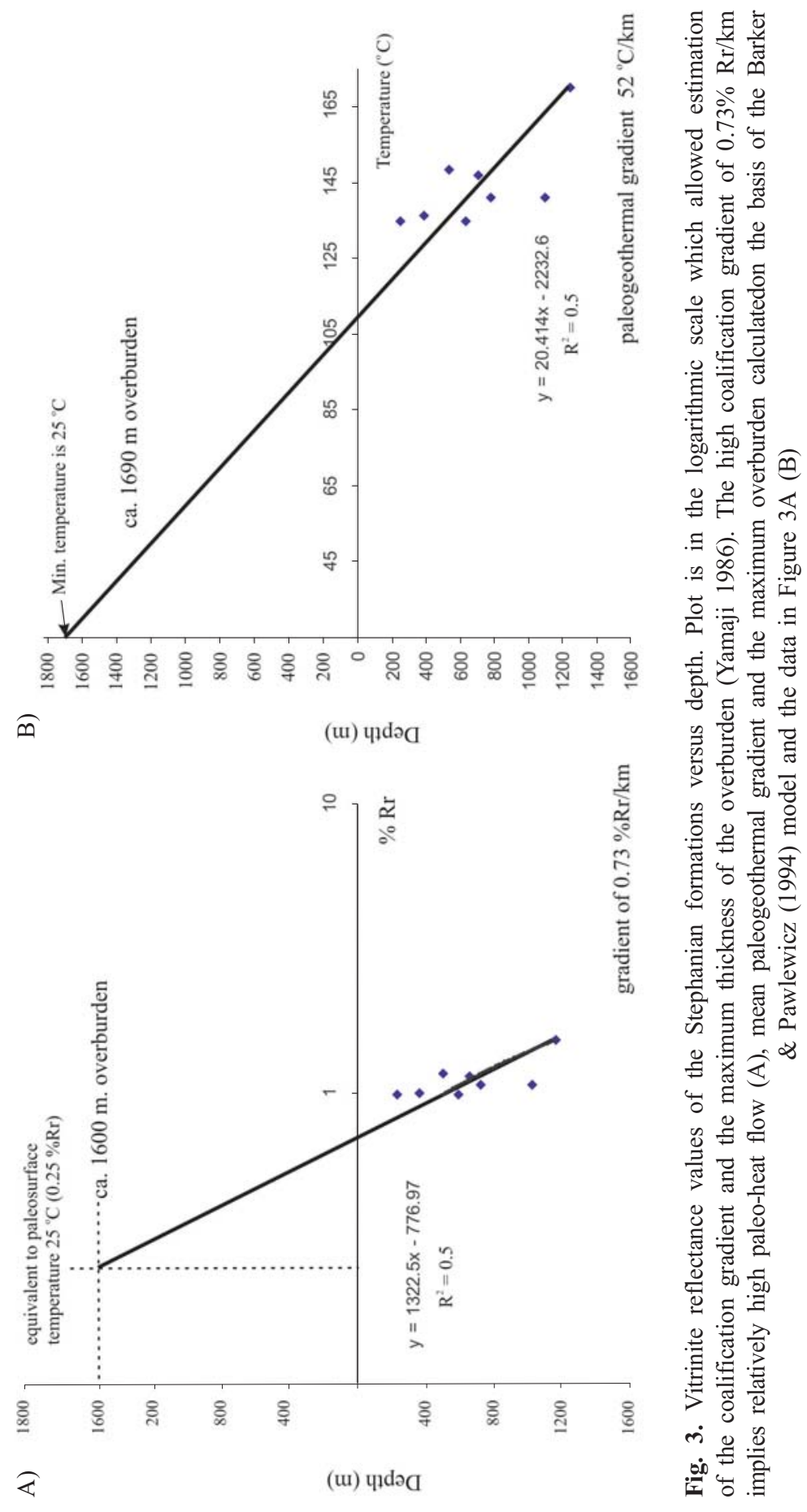



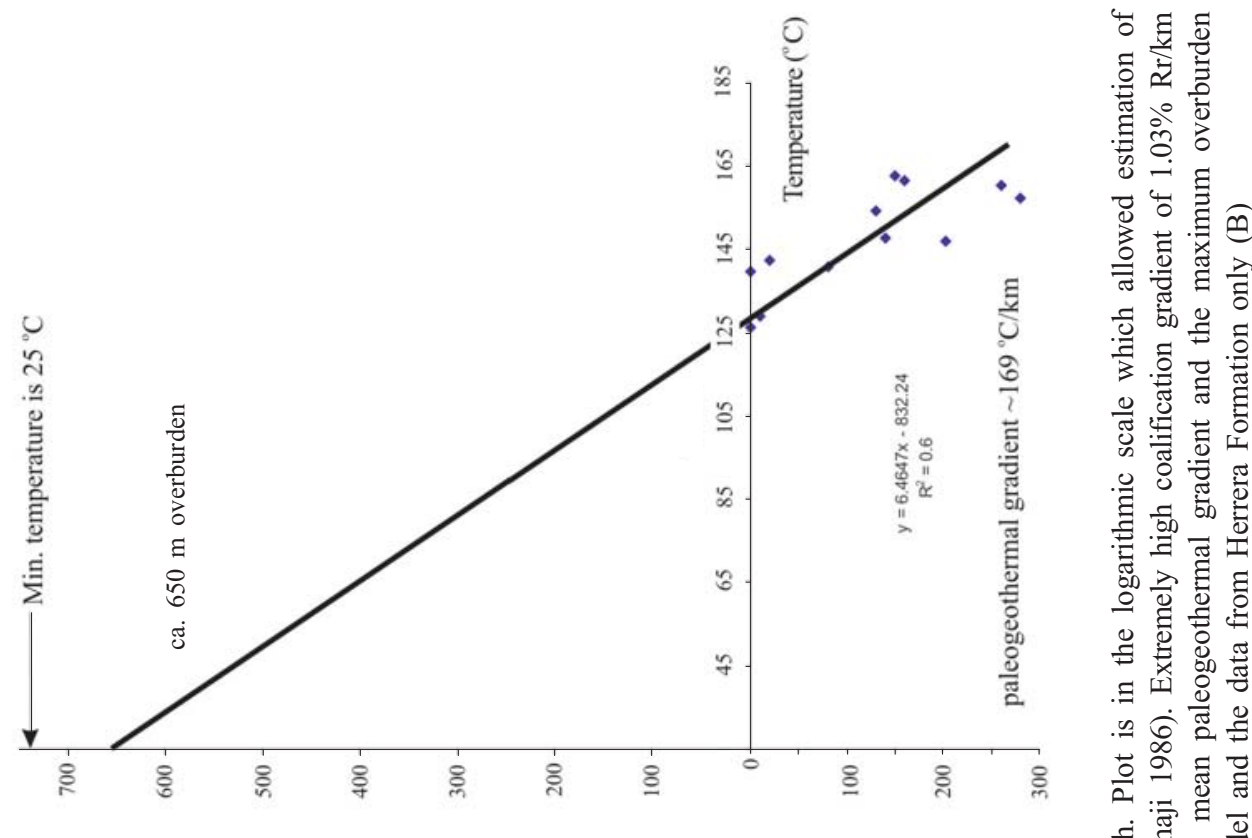

กิ

(ui) प1dəa

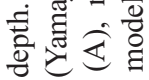

产产言委

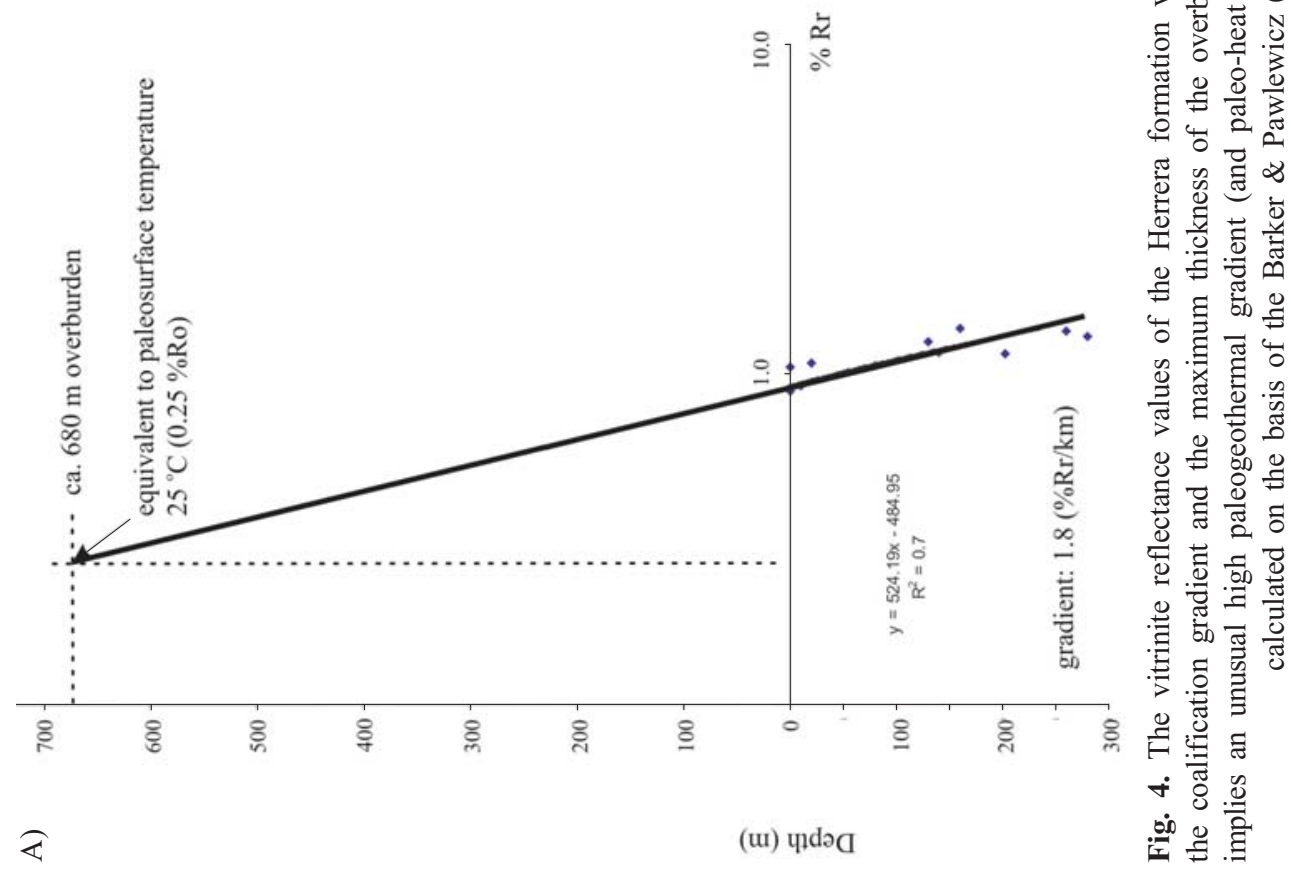


In contrast to the traditional concepts that consider organic maturation to be a function of both maximum burial temperature and effective heating time (e.g. Yalcin et al. 1997), the time-independent approach (Barker \& Pawlewicz 1994) has gained general acceptance recently for interpreting thermal histories of areas characterized by complex geological histories (e.g. Barker 1983, Barker \& Pawlewicz 1994, Akande \& Erdtmann 1998). While the application of time-temperature models is limited to first-cycle sedimentary basins with well known burial and thermal histories, the time-independent method based on several statistical correlations between vitrinite reflectance and peak temperature can be applied to complicated orogenic sequences (e.g. Laughland \& Underwood 1993) and hydrothermal systems (e.g. Barker 1983). Excellent correlations between fluid-inclusion homogenization temperature and vitrinite reflectance confirm temperature as the major control on organic maturation (e.g. Barker \& Pawlewicz 1994, Tobin \& Claxton 2000).

Fluid circulation can cause the increase of heat flow at shallow level in a short time by a factor of 5 over the basement heat flow (Gayer et al. 1998a, b). The Herrera Formation is situated in a highly tectonised area and the presence of internal faults cannot be excluded (see e.g. Knight et al. 2000), which would indicate intense fluid transport in the highly permeable layers. The Herrera Beds occupy the faulted core of the Sabero Syncline and are bounded by two major faults. Although, Herrera Formation has very restricted outcrops, historically they represent the principal productive coal seam interval of the mining operations, and were referred to as the Paquete Central for the Sotillos Mine. It was shown (Knight et al. 2000) that the principal worked sequence suffered intense tectonic deformation with probably at least three major thrust faulting events affecting the main seams and apparent subsequent refolding in association with later fault movements. The principal coal-bearing sequence of the Herrera Beds was originally believed to contain five or six significant workable seams within a total stratigraphic thickness of over $300 \mathrm{~m}$ (Knight 1983), but recently it has been reinterpreted to comprise up to three, steeply inclined thrust fault repetitions of no more than two principal seams (Fig. 4 in Knight et al. 2000). Such tectonic complexities cause additional problems with calculation of the geothermal paleogradient in this formation. Few vitrinite reflectance data are also given by Knight et al. (2000). They noticed an irregular pattern of relatively high reflectances $(1.4-1.8 \% \mathrm{Rr})$ in the strongly tectonized Unica and Herrera Formations, while more uniform range of lower values (1.2-1.3\% Rr) was found in the older sequences of the Sucessiva and Raposa Formations (Knight et al. 2000). Such values plotted against depth would give the coalification trend that is difficult to interpret. But this pattern suggests that different $\% \mathrm{Rr}$ vs. depth in each Stephanian formations were likely separated by faults. This idea is also supported by the present data (Tab. 1, Fig. 3A). Therefore, \% Rr depth-trend is likely oversimplified and have some uncertainty. In the Sabero Coalfield, the high \% $\mathrm{Rr}$ gradient imply that heat flow was high. Heat flow in extensional any pull-apart basins is typically in range of $\sim 100-150 \mathrm{~mW} / \mathrm{m}^{2}$ (e.g. Allen \& Allen 1990). Similarly, very high values of heat flow $\left(100-180 \mathrm{~mW} / \mathrm{m}^{2}\right)$ was given by Copard et al. (2000) for the intramontane coalfields of the Massif Central (France) as an evidence of hydrothermal fluid circulation which caused 
coalification. Additionally palaeo-heat flows in this range are reported from similar settings such as the Eastern Alps (Sachsenhofer 2001).

Colmenero et al. (2008) suggested recently that the high thermal fluxes associated with magmatic events provided the necessary temperature to accelerate the maturation of the Stephanian coalfields of the up to anthracite coal rank in the Cantabrian Mountains. However Sabero Coalfield is characterized by one of the lowest coal rank level of them, in which hydrothermal effects were not manifested so intensively. Therefore, other mechanisms, like burial, might be also important factor influencing the coalification process. For example in the Cinera-Matallana coalfield, the preferred values of the former overburden are estimated to be $\sim 1,050 \mathrm{~m}$, whilst not acceptable value for 2,000 m (Frings et al. 2004). They also calculated the average palogeothermal gradient in the Cinera-Matallana basin as high as $85^{\circ} \mathrm{C} / \mathrm{km}$, and paleo-heat flow as high as $150 \mathrm{~mW} / \mathrm{m}^{2}$ (Frings et al. 2004). In the Sabero Coalfield average palogeothermal gradient in the entire sedimentary succession was calculated on $52^{\circ} \mathrm{C} / \mathrm{km}$ (Fig. 3B). Geothermal gradients higher than normal may also be expected in organic-rich sediments due to their low thermal conductivity (Blackwell \& Steele 1989, Hower \& Gayer 2002). The organic-rich lithologies (including coals) are very thin compared to the dominantly clastic sedimentary strata of the Sabero Coalfield. The calculated average thermal conductivity values for the Stephanian formations (Tab. 2) are between 2.55-2.93 W/mK, therefore, the variations in geothermal gradients cannot be explained by lithostratigraphy.

The various equations describing coalification (e.g. Barker \& Goldstein 1990, Barker \& Pawlewicz 1994, Mullis et al. 2001) are applicable only to specific settings of particular thermal histories. However, as the calculated value for the overburden is in accordance with that obtained through the approach of Yamaji (1986), the calculated mean palaeo-geothermal gradient provides a good estimate of the palaeo-thermal history of the Sabero Coalfield. Nevertheless, the kinetic EASY \% Ro approach (Sweeney \& Burnham 1990) was used for calibration of the 1-D modelling of the empirical results. In order to obtain a good fit between measured and calculated vitrinite reflectance values, different scenarios were calculated with an iterative method using EASY \% Ro algorithm (Sweeney \& Burnham 1990) implemented in the PetroMod software. The time of maximum burial was most likely during the post-Stephanian B (Latest Stephanian to Early Permian), assuming deposition of sediments until Early Permian and subsequent exhumation and erosion (Julivert 1971, Heward 1978, Marcos \& Pulgar 1982).

Initially a model similar to Frings et al. (2004) was adopted with $150 \mathrm{~mW} / \mathrm{m}^{2}$ heat flow and erosion of 1,050 $\mathrm{m}$ of the Permian sequence. This model resulted in high overestimation of the coal rank, particularly, in the lower part of the profile (Fig. 5A). Therefore, further simulations were carried out in order to fit model to the data set. The best fit was achieved using a paleo-heat flow of $60 \mathrm{~mW} / \mathrm{m}^{2}$ for the time of maximum burial and a total overburden of 3,200 m (Fig. 5B). Such a low heat flow value is in disagreement with the high geothermal gradients derived from high vitrinite reflectance gradients (Figs 3B, 4B). Moreover, total overburden of 3200 is also unlikely from local geology data. There is no tectonic nappe or a thick pile of other sediments of that age in the study area. Therefore, a 3,200 $\mathrm{m}$ of 
eroded Permian overburden seems to be too high value. Martinez-García (1990) also predicted a Permian cover to have overlain the whole Cantabrian Zone. But it is considered unlikely that such a cover exceeded much more than 1,000 m thickness in the SCZ, as only very small outcrops of Permian strata are preserved in the north of the Cantabrian Zone. Similar conclusions have been also drawn by Frings et al. (2004). The burial history indicates rapid subsidence during the Stephanian to Early Permian times, followed by high erosion rate (Figs 5, 6). Estimated sedimentation rate for this period was about $400-800 \mathrm{~m} / \mathrm{Ma}$ depending on time of the Stephanian sedimentation (without taking into account the eroded overburden). It is considered very likely that overburden relates to further sedimentation in the latest Stephanian and in the Early Permian (Julivert 1971, Heward 1978, Marcos \& Pulgar 1982). Apatite fission track data from the neighbouring Cinera-Matallana Coalfield (Carriere 2006) suggest that the paleotemperature in the Stephanian rocks increased slightly in the Cretaceous times. This could be related to a Cretaceous sedimentary cover over the entire SCZ including both the Cinera-Matalana and Sabero coalfields. However, the Cretaceous burial probably did not exceed 500-900 m (Evers 1967, Heward 1978, Frings et al. 2002). It could not have influenced coalification of the Stephanian rocks. Moreover, the maximum paleotemperatures in the Stephanian rocks occurred in the Permian time (Carriere 2006). Therefore, a total overburden thickness, which was related to coalification of Stephanian rocks was deposited in the Early Permian and was less than $2000 \mathrm{~m}$.

In another modelling exercise (Fig. 6) a heat flow of $88 \mathrm{~mW} / \mathrm{m}^{2}$ and a total overburden of $1,650 \mathrm{~m}$ were used (based on the estimation from Fig. 3A). This amount of eroded overburden is more or less similar to the estimation in the Cinera-Matallana Coalfield (Frings et al. 2004). This model also produced fairly good fit with the measured \% Rr values (in the range of $95 \%$ confidence interval), but not for the upper part of the profile (Perla and Unica Formations) (Fig. 6). Nevertheless, the model presented in Figure 6 seems to be the most plausible from the point of view of the local geology, and it is therefore the preferred model. Lack of coincidence between the EASY \% Ro (Sweeney \& Burnham 1990) and Barker \& Pawlewicz (1994) algorithms can be attributed to a very short heating time, probably less than few million years (Sachsenhofer \& Littke 1992, Uysal et al. 2000, Buker 2002, Frings et al. 2004). Such a short thermal overprint can be related to relatively rapid fluid circulation in highly permeable rocks close to deep-sited faults like Sabero-Gordon, Olleros, La Llama, and others in the Sabero strike-slip basin. Uysal et al. (2000) argued that if coal maturation occurred during a short-lived heating event, Rr values could be translated safely into maximum paleotemperatures using the equations of Barker \& Pawlewicz (1994). The maximum paleotemperatures for the Stephanian rocks range between $~ 89$ (top of the Perla Formation) and $\sim 195^{\circ} \mathrm{C}$ (bottom of the Alejico Formation) (Fig. 6B). Ayllon et al. (2003) in fluid inclusion study in the Sabero and Cinera-Matallana coalfields estimated paleotemperatures in Sabero Coalfield from $73-129^{\circ} \mathrm{C}$ to $164-296^{\circ} \mathrm{C}$ in hydrothermal quartz crystals of the diorite sills of Permian age. Some of these are in direct contact to coal seams. Paleotemperatures calculated by Barker \& Pawlewicz (1994) method range from 135 to $170^{\circ} \mathrm{C}$ for the averages values from Stephanian formations of the Sabero Coalfield (Tab. 1) which fall into range of calculated values by EASY \% Ro method (Figs 5, 6). 


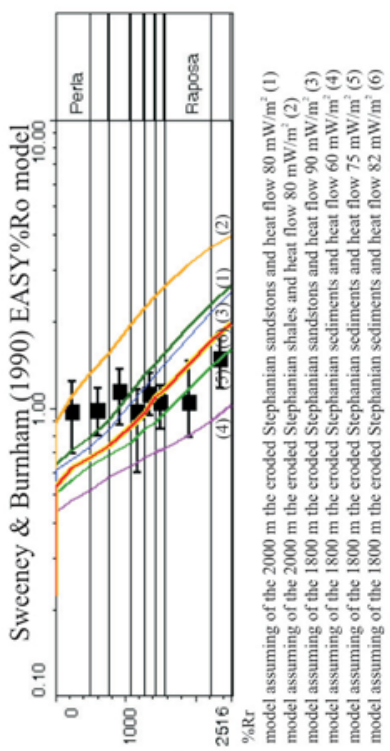

(u) पฺdəव

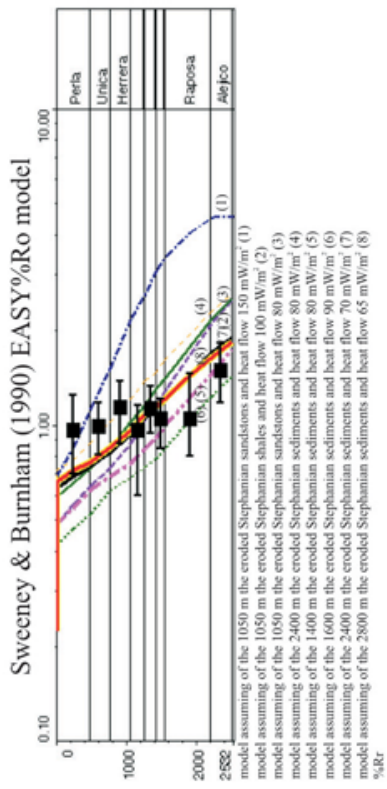

(uI) पıdə

«

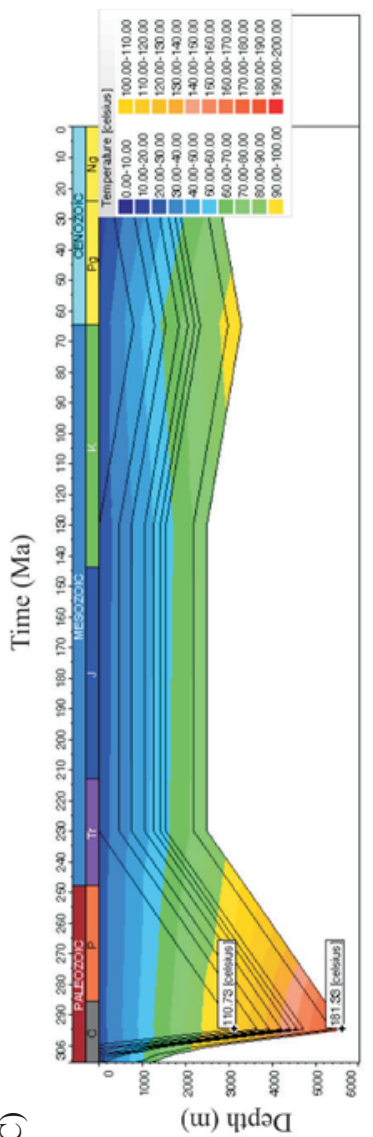

恖

$\otimes \frac{1}{2} 0$

ญे

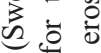

흥 긍

घ

ฉิ

ㅇำ

$\succ \doteq$

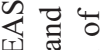

그융

ข

芛

导

幽进

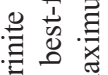

$\stackrel{5}{ }$

(1)

응.

冚苟

을 크

ชु

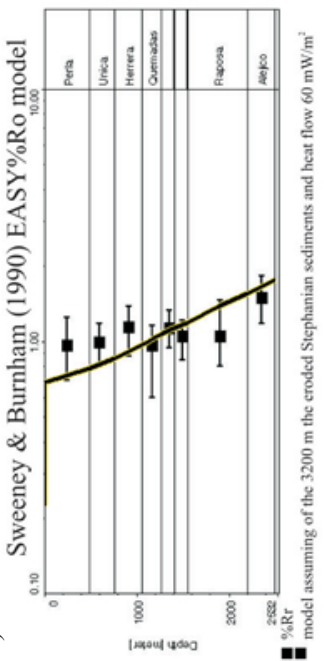

플

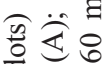

?

롱

芯

है

․ㅡㄹ 흥

ల్

每

공ํํ

魚 을

류

نั

ن

ํㅗㅇ 


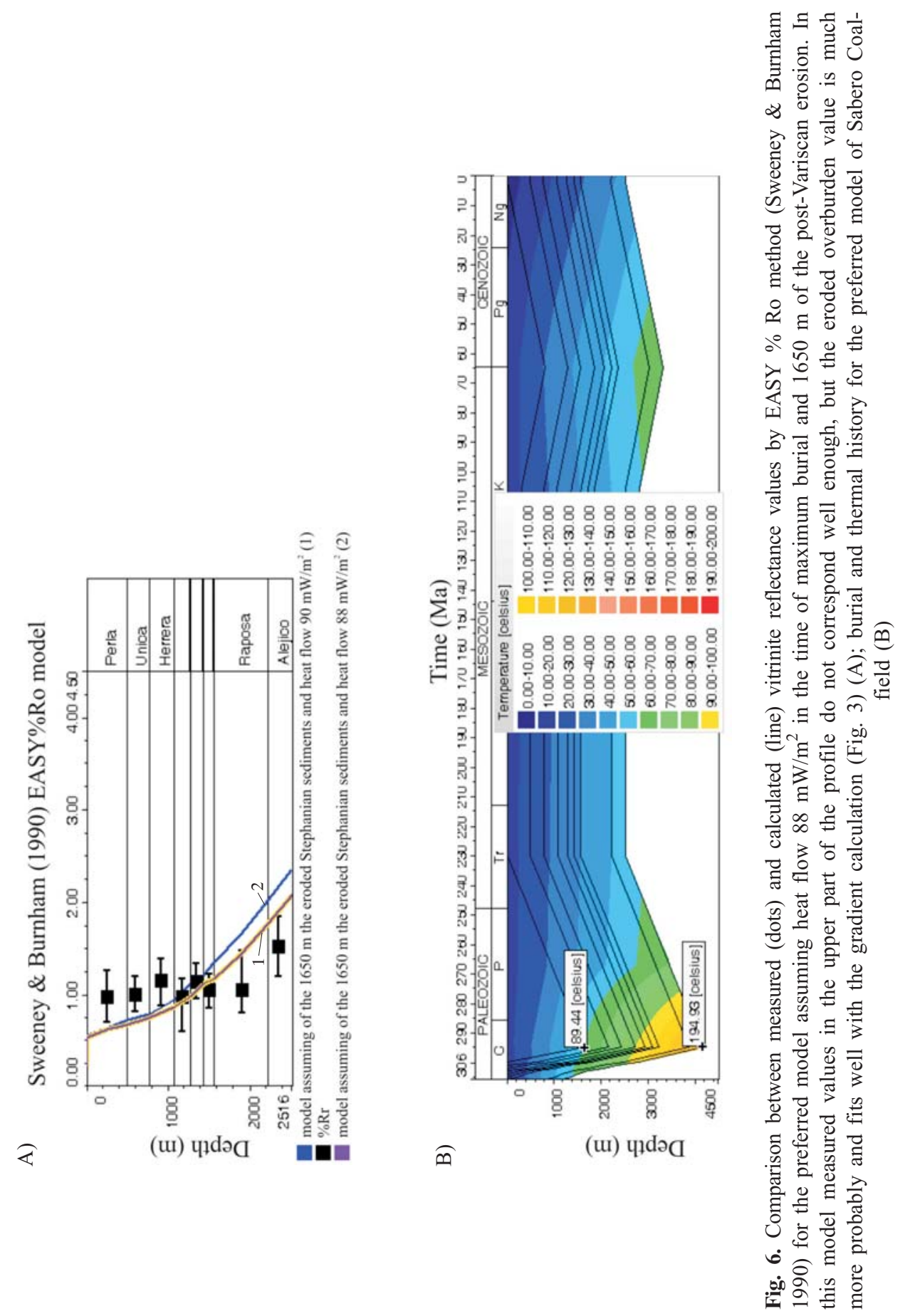


Additional model was tested using only \% Rr data from the Herrera beds (Fig. 7), in which a heat flow $150 \mathrm{~mW} / \mathrm{m}^{2}$ and a total overburden of $700 \mathrm{~m}$ produced a good fit, but only for the Herrera beds. Both upper and lower parts of the calculated model do not support \% Rr data from other Stephanian formations. Calculated values for the Herrera beds express very high heat flow even if calculated with significant error. Comparison between EASY \% Ro and Barker \& Pawlewicz (1994) results suggest that the latter approach seems to be the most appropriate for the Southern Cantabrian Zone coalfields (see also Frings et al. 2004). High paleo-heat flow values estimated in the Sabero Coalfield $\left(88 \mathrm{~mW} / \mathrm{m}^{2}\right)$, and particularly in the Herrrera Formation $\left(150 \mathrm{~mW} / \mathrm{m}^{2}\right)$, seem to be related to short-term (below 1-3 Ma) fluid migration in the Latest Variscan phases (or post-Variscan) in the Early Permian. This would imply that coalification related to primary burial, under likely mild geothermal conditions, was overprinted by the rapid hydrothermal processes, which are supposed to happen in the Early Permian time.

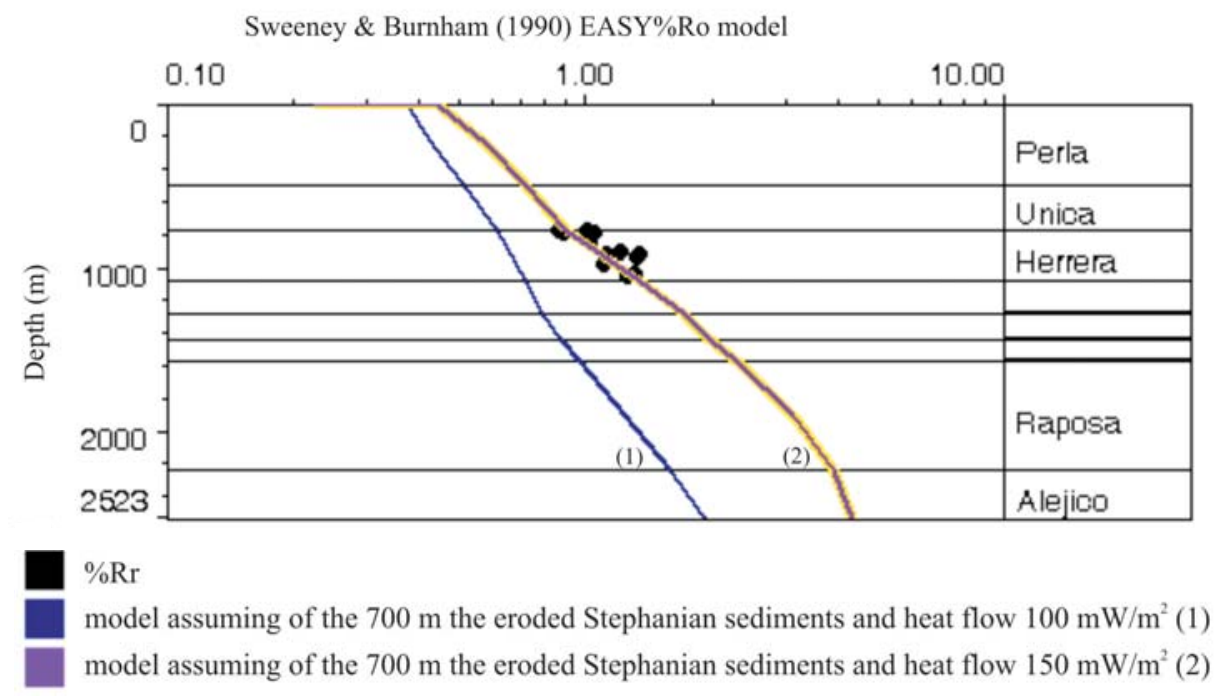

Fig. 7. Comparison between measured (dots) and calculated (line) vitrinite reflectance values by EASY \% Ro method (Sweeney \& Burnham 1990) for the Herrera Formation model assuming heat flow $150 \mathrm{~mW} / \mathrm{m}^{2}$ in the time of maximum burial and $700 \mathrm{~m}$ of the post-Variscan erosion

The Stephanian deposits in the Sabero Coalfield achieved probably their maximum coal rank in Early Permian time (Fig. 8) independently on which of the applied models is taken into account (Figs 5-7). An important factor, which influenced coalification of organic matter in the Stephanian rocks was undoubtedly related to syn-sedimentary magmatic activity in the Late Variscan as well post-Variscan. It seems that the widespread magmatism in the Late Variscan times in the Cantabrian Zone relates to delamination of the crust and upwelling of the astenosphere (Munoz et al. 1985, Fernández-Suárez et al. 2000). This magmatism could also have activated hydrothermal fluids migration, especially in areas 
of deep-seated faults, like in the Sabero Coalfield. However, the non-linear shape of the coalification curves (Figs 3A, 4A) could be caused by hydrothermal fluid migration and/or brittle tectonics. Therefore, it is difficult at this stage of research to assess with certainty, which of the factors factor had major, unique influence on the coal rank.

A)

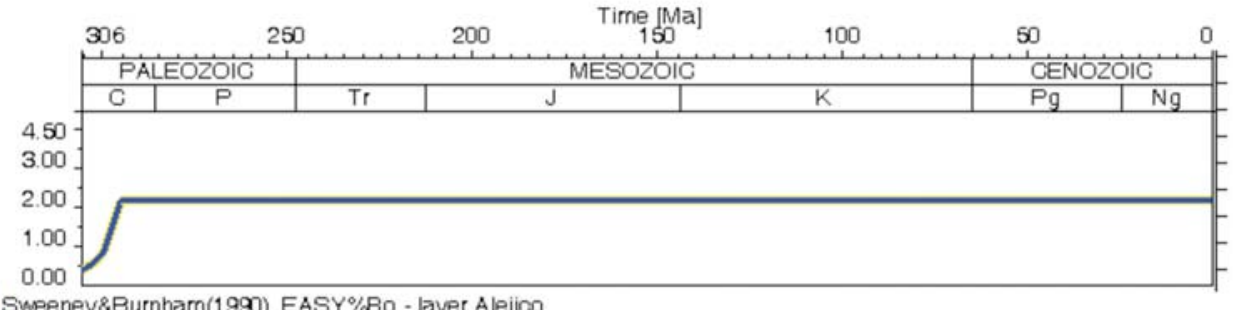

Smeeney\&Burnham(1990)_EASY\%Ro - layer Alejico

B)

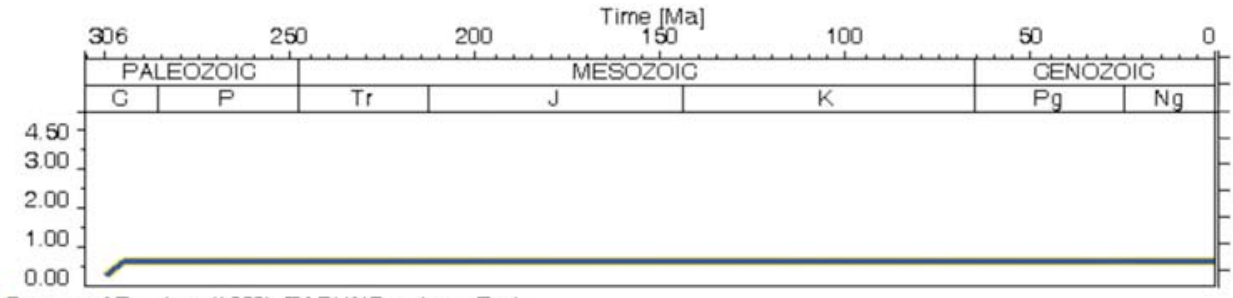

Sweeney\&Bumham(1990)_EASY\%Ro - layer Perla

Fig. 8. Timing of the coalification for the top (A) and bottom (B) of the Stephanian sedimentary succession in the Sabero Coalfield

The Cantabrian Zone is essentially regarded as a non-metamorphic unit. Several studies dealing with illite crystallinity, vitrinite reflectance, cleavage development and conodont colour alteration index have been published (Brime 1985, Aller et al. 1987, Alonso \& Brime 1990, Colmenero \& Prado 1993, García-López et al. 1997, Bastida et al. 1999, Brime et al. 2001). They have shown the distribution and main features of the various zones within the transition from diagenesis to metamorphism, formed during at least two episodes of low-temperature metamorphism in the Cantabrian Zone, which influenced the Carboniferous sediments. In the southern Cantabrain Zone Stephanian coal-bearing basins are distributed along strike-slip faults, formed as a consequence of transtensional movements, which migrated westward with time during the late stages of the Variscan orogeny. The basinal sediments generally have high coal rank, which in many occasions are higher than the Westpahalian foreland and intrathrust coal basins in the same region (see Colmenero et al. 2008). Colmenero \& Prado (1993) consider the rank to depend on the structural location of the coalfields. Aller et al. (2005) showed that the last thermal episode occurred during the Permian. It was produced by heat flow due to hydrothermal fluids, whose migration was favoured by faults, which is supported by this study. The effects of this episode are irregularly distributed, and they are apparent in the unconformable Stephanian rocks. 
The Paleozoic rocks in the Cantabrian Zone underwent intense thin-skinned tectonics, diagenetic to epizonal thermal events, and several episodes of fluid flow causing large-scale hydrothermal dolomitization (e.g. Gómez-Fernández et al. 2000, Gasparrini et al. 2001, Ayllon et al. 2003, Aller et al. 2005). Main pathways for the fluids were the Variscan thrust and fault planes. Extensional tectonics may have promoted a gravity driven flow of fluids, which circulated deeply down and underwent heating (Gasparrini et al. 2003). The highest coal ranks are being likely linked to hydrothermal heat flows related to the presence of major deep faults. Locally variable porosity and the degree of compaction of the Stephanian sequence might play an important role in the development of the coalification pattern. Relatively uncompacted and lithified sediment would facilitate fluid circulation, whereas heat transfer would be more effective at such early diagenetic stage (Duddy et al. 1994). Therefore, any related fluid activity that would reflect anomalous thermal gradients may be expected to have left an imprint upon the Stephanian clastic deposits. Studies of fluid inclusions of the southern Cantabrian Zone showed fracture-controlled fluid flow along steep systems associated with thrusts and/or with strike-slip faults (Gómez-Fernández et al. 2000, Gasparrini et al. 2001, Ayllon et al. 2003).

Irregular thermal maturity pattern may be related to short-lived fluid migration in the Stephanian rocks, which caused overprinting of the initial burial diagenesis. The reconstruction of the thermal history of the Sabero Coalfield was best achieved with the empirical equation of Barker \& Pawlewicz (1994). Thermal modelling with favoured EASY \% Ro method results a good fit but with a minor geological relevance. Only with additional information about the basin evolution the more realistic reconstruction could be developed.

\section{CONCLUSIONS}

1. The vitrinite reflectance values in the Stephanian rocks in the Sabero Coalfield are in the range of 0.61 to $3.14 \% \mathrm{Rr}$, but the most values are limited to the range of 0.8 to $1.5 \% \operatorname{Rr}$ (based on 84 samples).

2. Average vitrinite reflectance gradient for the entire succession is high $(0.73 \% \mathrm{Rr} / \mathrm{km})$, which suggests a high paleogeothermal gradient $\left(52^{\circ} \mathrm{C} / \mathrm{km}\right)$.

3. The maximum paleotemperatures calculated from vitrinite reflectance data for the Stephanian rocks ranged between $89^{\circ} \mathrm{C}$ (top of the Perla Formation) and $195^{\circ} \mathrm{C}$.

4. Coalification of organic matter contained in the Stephanian rocks was achieved in the Early Permian. It was probably related to several almost simultaneously operating processes, the most important of which were magmatic and hydrothermal activity and high subsidence in this pull-apart basin. High palaeogeothermal gradients estimated in the Sabero Coalfield may be interpreted to result from convective heat transfer during a hydrothermal event. Variable heat distributions, due to localized fracture-enhanced permeable zones acting as hot reservoirs in the deeper part of the basin, may have been responsible for some significant local thermal anomalies. Therefore, the primary burial-related coalification pattern was probably overprinted by short-term fluid migration event, which is thought to have occurred in Early Permian time. 
I would like to thank Dr. J.A. Knight (Derby, UK) for giving me access to the tonstein samples from the Sabero Coalfield and introduction to regional geology of the Sabero Coalfield, Prof. C. Brime (University of Oviedo, Spain) for productive discussions and detailed maps of the Southern Cantabrian Zone, Dr. A. Drobniak (Indiana Geological Survey, Bloomington, USA) for reading the manuscript and useful remarks improving the text, as well as reviewers for their valuable input to improve the paper.

This project was financed by the Polish Ministry of Science grant no. 2307/T02/2007/32 (AGH No. 18.18.140.542) and AGH internal projects (No. 10.10.140.153).

\section{REFERENCES}

Akande S.O. \& Erdtmann B.D. 1998. Burial metamorphism in Cretaceous sediments of the southern Benue Trough and Anambra Basin, Nigeria. AAPG Bulletin, 82, 1191-1206.

Allen P.A. \& Allen J.R., 1990. Basin analysis: principles and applications. Blackwell, Oxford.

Aller J., 1986. La estructura del sector meridional de las unidades del Aramo y de la Cuenca Carbonífera. Consejería de Industria y Comercio, Oviedo.

Aller J. \& Brime C., 1985. Deformación y metamorfi smoen la parte sur de la Cuenca Carbonifera Central (Espańa). X Congress of the Carboniferous, Madrid, 541-548.

Aller J., Bastida F., Brime C. \& Pérez-Estaún A., 1987. Cleavage and its relation with metamorphic grade in the Cantabrian Zone (NW Spain). Bulletin de la Societé Géologique de France, 40, 1-8.

Aller J., Valin M.L., García-Lopez S., Brime C., \& Bastida F., 2005. Superposition of tectono-thermal episodes in the southern Cantabrian Zone, NW Spain. Bulletin de la Societé Géologique de France, 176, 487-497.

Alonso J.I. \& Brime C., 1990. Mineralogy, geochemistry and origin of the underclays of the Central Coal Basin, Asturias, Spain. Clays and Clay Minerals, 38, 265-276.

Alonso J.L., Pulgar J.A., García Ramos J.C., \& Barba P., 1995. Tertiary basins and Alpine tectonics in the Cantabrian Mountains (NW Spain). [in:] Friend P.F. \& Dabrio C.J. (eds), Tertiary basins of Spain, Cambridge University Press, 214-227.

Ayllon F., Bakker R.J. \& Warr L.N., 2003. Re-equilibration of fluid inclusions in diageneticanchizonal rocks of the Cinera-Matallana coal basin (NW Spain). Geofluids, 3, 49-68.

Barker C.E. \& Goldstein R.H., 1990. Fluid-inclusion technique for determining maximum temperature in calcite and its comparison to the vitrinite reflectance geothermometer. Geology, 18, 1003-1006.

Barker C.E \& Pawlewicz M.J., 1994. Calculation of vitrinite reflectance from thermal histories. A comparison of methods. [in:] Mukhopadahay P.K. \& Dow. W.G. (eds), Vitrinite reflectance as a maturity parameter: applications and limitations, American Chemical Society Symposium Series, 570, 216-229. 
Barker C.E., 1983. Influence of time on metamorphism of sedimentary organic matter in liquid-dominated geothermal and hydrothermal alteration zones in the sandstones, western North America. Geology, 11, 384-388.

Bastida F., Brime C., García-Lopez S. \& Sarmiento G.N., 1999. Tectono-thermal evolution in a region with thin-skinned tectonics, the western nappes in the Cantabrian Zone (Variscan Belt of NW Spain). International Journal of Earth Sciences, 88, 38-48.

Blackwell D.D. \& Steele J.L., 1989. Thermal conductivity of sedimentary rocks: measurement and significance. [in:] Naeser N.D., McCulloh T.H. (eds), Thermal History of Sedimentary Basins: Methods and Case Histories, Springer-Verlag, New York, 13-36.

Botor D., 2005. Geochemistry of Stephanian tonsteins from the Sabero Coalfield (NW Spain). Geological Transactions of the Silesian University of Technology, 268, 19-30.

Botor D., 2009. Paleogeothermal evolution of the Sabero Coalfield. Report of project the Polish Ministry of Science and Higher Education, no. 2307/T02/2007/32.

Brime C., 1985. A diagenesis to metamorphism transition in the Hercynian of NW Spain. Mineralogical Magazine, 49, 481-484.

Brime C., García-Lopez S., Bastida F., Valin M.L., Sanz-Lopez J. \& Aller J., 2001. Transition from diagenesis to metamorphism near the front of the Variscan regional metamorphism (Cantabrian Zone, NW Spain). Journal of Geology, 109, 363-379.

Buker C., 2002. Paleotemperaturindikatoren und ihre geologische Interpretation. [on line:] http://www.rwth-aachen.de/lek/Ww/CBPalaeotemp.html.

Carriere K.L., 2006. Neoproterozoic to Holocene tectonothermal evolution of the southern Cantabrian Mountains NW Iberia, revealed by apatite fission-track thermochronology. Heidelberg University [Ph.D. Thesis].

Cepedál M.A., Martín-Izard A., Reguilon R., Fuertes M., Rodríguez-Pevida L.S., Maldonado C., Spiering E., Gonzáles S. \& Varela A., 1998. Stable isotopic study of the El Valle-Boinas Co-Au deposits. [in:] Arias D., Martín-Izard A. \& Paniagua A. (eds), Gold in NW Spain, Departamento de Geología, Oviedo, 59-64.

Colmenero J.R. \& Prado J.G., 1993. Coal basins in the Cantabrian Mountains, NW Spain. International Journal of Coal Geology, 23, 215-229.

Colmenero J.R., Suárez-Ruiz I., Fernández-Suárez J., Barba P. \& Llorens T., 2008. Genesis and rank coal basins in the Cantabrian Mountains, NW Spain. International Journal of Coal Geology, 76, 187-204.

Colmenero-Navarro J.R., Garcýa-Ramos J.C., Gutierrez-Elorza M., Lopez-Martýnez N., Manjon-Rubio M., Molina E. \& Vargas-Alonso I., 1982. Memoria explicativa de la Hoja del Mapa Geologico Nacional Espania. 1:50.000, num. 131, Cistierna. 2a serie MAGNA. Instituto Geológico y Minero de España, Madrid.

Copard Y., Disnar J.R., Becq-Giraudon J.F. \& Boussafir M., 2000. Evidence and effects of fluid circulation on organic matter in intramontane coalfields (Massif Central, France). International Journal of Coal Geology, 44, 49-68.

Corretgé L.G. \& Suárez O., 1990. Igneous rocks. [in:] Dallmeyer R.D. \& Martínez-García E. (eds), Pre-Mesozoic geology of Iberia, Springer, Berlin, 72-79. 
Crespo J.L., Moro M.C., Fadón O., Cabrera R. \& Fernández A., 2000. The Salamón gold deposit (León, Spain). Journal of Geochemical Exploration, 71, 191-208.

Dallmeyer R.D., Martínez-Catalán J., Arenas R., Gillbarguchi J.I., Gutiérrez-Alonso G., Farias P., Bastida F. \& Aller J. 1997. Diachronous Variscan tectonothermal activity in the NW Iberian Massif: evidence from 40Ar/39Ar dating of regional fabrics. Tectonophysics, 277, 307-337.

Duddy I.R., Green P.F., Bray R.J. \& Hegarty K.A., 1994. Recognition of the thermal effects of fluid flow in sedimentary basins. [in:] Parnell J. (ed.), Geofluids: Origin, Migration and Evolution of Fluids in Sedimentary Basins, Geological Society Special Publication, 78, 325-345.

Evers H.J., 1967. Geology of the Leonides between the Bernesga and Porma Rivers, Cantabrian Mts. Spain. Leidse Geologische Mededelingen 44, 81-151.

Fernández C.J., Moreiras D. \& Paniagua A., 1985. Mineralogía y paragénesis mineral de la Mina Providencia (Cármenes, León). Trabajos de Geologia, 15, 239-247.

Fernández-Suárez J., Dunning G.R. \& Jenner G.A., 2000. Variscan collisional magmatism and deformation in NW Iberia: constrains form $\mathrm{U}-\mathrm{Pb}$ geochronology of granitoids. Journal of the Geological Society, 157, 565-576.

Frings K.H., 2002. Palaeotemperature anomalies in late-Variscan coal basins,based on Cinera-Matallana basin, Cantabrian Zone, NW Spain. Heidelberg University, Germany, Gaea Heidelbergensis, 11, 1-128 [Ph.D. Thesis].

Frings U., Lutz R., de Wall H. \& Warr L.N, 2004. Coalification history of the Cinera-Matallana pull-apart basin (NW Spain). International Journal of Earth Sciences, 93, 92 106.

Galán G. \& Suárez O., 1989. Cortlanditic enclaves associated with calcalkaline granites from Tapia-Asturias (Hercynian Belt, NW Spain). Lithos, 23, 233-245.

Galán G., Pin C. \& Duthou J.L., 1996. Sr-Nd isotopic record of multi-stage interactions between mantle derived magmas and crustal components in a collision context. The ultramafic-granitoid association from Vivero (NW Spain). Chemical Geology, 131, 67-91.

Gallastegui G., Heredia N., Rodríguez-Fernández L.R. \& Cuesta A., 1990. El stock de Peńa Prieta en el contexto del magmatismo de la Unidad del Pisuerga-Carrión (Zona Cantábrica, Espańa). Cadernos do Laboratorio Xeolóxico de Laxe, 15, 203-217.

García-López S., Bastida F., Brime C., Aller J., Valín M.L., Sanz-López J., Méndez C.A. \& Menéndez-Álvarez J.R., 1999. Los episodios metamórficos de la Zona Cantábrica y su contexto estructural. Trabajos de Geologia, 21, 177-187.

García-López S., Brime C., Bastida F. \& Sarmiento G.N. 1997. Simultaneous use of thermal indicators to analyse the transition from diagenesis to metamorphism: an example from the Variscan Belt of NW Spain. Geological Magazine, 134, 323-334.

Gasparrini M., Bakker R.J, Bechstaedt T., \& Boni M., 2003. Hot dolomites in a Variscan foreland belt - hydrothermal flow in the Cantabrian Zone (NW Spain). Journal of Geochemical Exploration, 78-79, 501-507. 
Gayer R.A., Garven G. \& Rickard D.T., 1998a. Fluid migration and coal-rank development in foreland basins. Geology, 26, 679- 682.

Gayer R.A., Hathaway T.M. \& Nemcok M., 1998b. Transpressionaly driven rotation in the external orogenic zones of the Western Carpathians and the SW British Varicides. [in:] Holdsworth R.E., Strachan R.A. \& Dewey, J.F. (eds), Continental Transpressional and Transtensional Tectonics, Geological Society of London, Special Publication, 135, $235-266$.

Gómez-Fernández F., Both R.A., Mangas J. \& Arribas A. 2000. Metallogenensis of Zn-Pb Carbonate-Hosted mineralisation in the south-eastern region of the Picos de Europa (Northern Spain) province: geologic, fluid inclusion and stable isotope studies. Economic Geology, 95, 19-40.

Gutiérrez J.L., Rodríguez-Pevida L.S. \& Paniagua, A., 1988. Las mineralizaciones poliminerálicas de $\mathrm{Pb}-\mathrm{Zn}-\mathrm{Sb}-\mathrm{Ag}-\mathrm{Au}$ de Escaro (León): controles geológicos, evolucíon mineralógica y implicaciones metalogénicas. Bulletin of Mineralogical Society, Spain, $11,120-121$.

Gutiérrez-Alonso G., Fernández-Suárez J. \& Weil A.B. 2004. Orocline triggered lithospheric delamination. Geological Society of America Special Papers, 383, 121-131.

Heward A.P., 1978. Alluvial fan and lacustrine sediments from the Stephanian A and B (La Magdalena, Sabero and Cinera-Matallana coalfields) NW Spain. Sedimentology, 25, 451-488.

Heward A.P. \& Reading, H.G., 1980. Deposits associated with a Hercynian to late Hercynian continental strike-slip system, Cantabrian Mountains, Northern Spain. Special Publication International Association of Sedimentologist, 4, 105-125.

Hower J.C. \& Gayer R.A., 2002. Mechanisms of coal metamorphism: case studies from Paleozoic coalfields. International Journal of Coal Geology, 50, 215-245.

International Organization for Standardization (ISO), 1994. Methods for the Petrographic Analysis of Bituminous Coal and Anthracite - Part 5: Methods Determining Microscopically the Reflectance of Vitrinite. ISO 7404-5, Geneva, Switzerland. 1-11.

Julivert M., 1971. Décollement tectonics in the Hercynian Cordillera of NW Spain. American Journal of Science, 270, 1-29.

Knight J.A., 1983. The Stratigraphy of the Stephanian rocks Sabero Coalfield, NW Spain. Paleontographica 187, 1-89.

Knight J.A., Burger K. \& Bieg G., 2000. The pyroclastic tonsteins of the Sabero Coalfield, north-western Spain, and their relationship to the stratigraphy and structural geology. International Journal of Coal Geology, 44, 187-226.

Laughland M.M. \& Underwood M.B., 1993. Vitrinite reflectance and estimates of paleotemperature within the Upper Shimanto Group, Japan. Geological Society of America Special Publication, 273, 103-114.

López-Gómez J., Arche A. \& Pérez-López A. 2002. Permian and Triassic. [in:] Gibbons W. \& Moreno T. (eds), The Geology of Spain, The Geological Society, London, 185-212.

Loredo J. \& García-Iglesias J., 1988. El yacimiento aurífero de Carlés (Asturias). Bulletin of Mineralogical Society, Spain. 11, 47-54. 
Luque C., Martínez-García E. \& Ruiz F., 1990. Metallogenesis. [in:] Dallmeyer R.D. \& Martínez-García E. (eds), Pre-Mesozoic geology of Iberia, Springer, Berlin, 80-87.

Manjon-Rubio M., Colmenero-Navarro J.R., Garcýa-Ramos J.C., Gutierrez-Elorza M., Molina E., Vargas-Alonso I., 1982. Memoria explicativa de la Hoja del Mapa Geologico Nacional Espania. 1:50.000, num. 130, Vegas del Condado. 2a serie MAGNA. Instituto Geológico y Minero de España, Madrid.

Marcos A. \& Pulgar JA., 1982. An approach to the tectonostratigraphic evolution in the Cantabrian Foreland thrust and fold belt, Hercynian Cordillera of NW Spain. Neues Jahrbuch. Geologie und Paläontologie, 163, 2, 256-260.

Martínez-Catalán J.R., Arenas R., Díaz-García F. \& Abati J., 1997. Variscan acretionary complex of NW Iberia: Terrane correlation and succession of tectonothermal events. Geology, 25, 12, 1103-1106.

Martinez-García E., 1990. Stephanian and Permian basins. [in:] Dallmeyer R.D. \& Martinez-García E. (eds), Pre-Mesozoic geology of Iberia, Springer, Berlin, Heidelberg, New York, 39-54.

Mendez C.A.F., 1985. Estudio de la evolucion de los carbones de la cuenca Cinera-Matallana, Leon. University Oviedo, Spain [Ph.D. Thesis].

Mullis J., Wolf M., \& Ferreiro-Mahlmann R., 2001. Temperature determination through fluid inclusion microthermometry and vitrinite reflectance in the diagenetic- and anchizones. Journal of Conference Abstracts European Geosciences Union, XI, 6, 230.

Munoz M., Anchoca E., Sagredo J., Hernan F., Brandle J. \& Marfil R., 1985. Vulcanismo Permo-Carbonifero de la Cordillera Iberica. $10^{\text {th }}$ Congres of Carboniferous, Madrid, $27-52$.

Noth S., Thomson R., \& Littke R., 2002. A method for assessment statistical significance and uncertainties for calibration 1-D thermal maturation models. AAPG Bulletin, 86, 417-431.

Oncken O., 1982. Basin reconstruction by coalification studies. Geologische Rundschau, 71, 579-602.

Paniagua A., Loredo J. \& García-Iglesias J., 1995. Epithermal carbonate-hosted Au-Cu-Ni-Co mineralization at the Villamanín area (Cantabrian Zone, N Spain). Bulletin of Mineralogical Society, Spain, 18, 1, 172-173.

Paniagua A., Rodríguez-Pevida L.S., Loredo J., Fontboté L. \& Fenoll Hach-Ali P., 1996. Un yacimiento de $\mathrm{Au}$ en carbonatos del Orógeno Hercínico: el área de Salamón (N León). Geogaceta, 20, 7, 1605-1608.

Pérez-Estaún A., Bastida F., Alonso J.L., Marquinez J., Aller J., Alvarez-Marrón J., Marcos A. \& Pulgar J.A., 1988. A thin-skinned tectonics model for a fold and thrust belt of the Cantabrian Zone. Tectonics, 7, 517-537.

Piedad-Sánchez N., Suárez-Ruiz I., Martinez L., Izart A., Elie M., \& Keravis D., 2004a. Organic petrology and geochemistry of the Carboniferous coal seams from the Central Asturian Coal Basin (NW Spain). International Journal of Coal Geology, 57, 211-242. 
Piedad-Sánchez N., Izart A., Martínez L., Suárez-Ruiz I., Elie M. \& Menetrier C., 2004b. Paleothermicity in the Central Coal Basin of the Cantabrian Mountains (Spain). International Journal of Coal Geology, 58, 205-229.

Raven J.G.M. \& Van der Pluijm B.A., 1986. Metamorphic fluids and transtention in the Cantabrian Mountains of northern Spain: an application of the conodont colour alteration index. Geological Magazine, 123, 6, 673-681.

Reading H.G., 1975. Strike-slip fault systems: an ancient example form the Cantabrians (Spain). IX International Congress Sedimentology, Nice, 1975, Theme 4, 2, 287-292.

Robert P., 1988. Organic Metamorphism and Geothermal History. Academic Press, Elf-Aquitaine \& Reidel, Dordrecht, 3-26.

Rodriguez-Fernandez L.R., Heredia N. \& Alonso J.L., 1988. Mapa Geologica de Espania. 1:50.000, num. 105-15-07, Riano. Instituto Geológico y Minero de España, Madrid, Espania.

Rodriguez-Fernandez L.R., Alonso J.L., Alonso-Herrero E., Barba P., Colmenero-Navarro J.R., Fernandez L.P., Galan L., Gallastegui G., Heredia N. \& Paniagua A., 1990. Memoria explicativa de la Hoja del Mapa Geologico Nacional Espania. 1:50.000, num. 105, Riano. 2a serie MAGNA. Instituto Geológico y Minero de España, Madrid, Espania.

Rodriguez-Fernandez L.R., Lobato L., García-Alcalde J.L., Sanchez de Posada L.C. \& Trouyols J., 1979. Mapa Geologica de Espania. 1:50.000, num. 104-14-07, Bonar. Instituto Geológico y Minero de España, Madrid, Espania.

Rodriguez-Fernandez L.R., Perez-Gonzalez A., Munioz E.E., Rubio M.M., Vargas Alonso I., Colmenero J.R., García-Ramos J.C. \& Matas-Gonzalez J. 1978. Mapa Geologica de Espania. 1:50.000, num. 130-14-08, Vegas de Condado. Instituto Geológico y Minero de España, Madrid, Espania.

Sachsenhofer R.F., 2001. Syn- and post-collisional heat flow in the Cenozoic Eastern Alps. International Journal of Earth Science, 90, 579-592.

Sachsenhofer R.F. \& Littke R., 1992. Vergleich und Bewertung verschiedener Methoden zur Berechnung der Vitrinitreflexion am Beispiel von Bohrungen im Steirischen Tertiarbecken. Zentralblatt für Geologie und Paläontologie, 6, 597-610.

Spiro B., Tornos F. \& Shepherd T.J., 1995. Stable isotope characterization of barren and mineralized Hercynian hydrothermal carbonates in the Cantabrian Zone (N Spain). [in:] Pasava J., Kríbek B. \& Zák K. (eds), Mineral deposits: from their origin to environmental impacts, Balkema, Rotterdam, 75-78.

Sweeney J.J. \& Burnham A.K., 1990. Evaluation of a model of vitrinite reflectance based on chemical kinetics. AAPG Bulletin, 74, 1559-1570.

Teichmuller M., 1987a. Recent advances in coalification studies and their application to geology. [in:] Scott A.C. (ed.), Coal and coal-bearing strata: recent advances, Geological Society Special Publication, 32, 127-169.

Teichmuller M., 1987b. Organic material and very low-grade metamorphism. [in:] Frey M. (ed.), Low-temperature metamorphism, Blackie \& Son, Glasgow, 114-161. 
Tobin R.C. \& Claxton B.L., 2000. Multidisciplinary thermal maturity studies using vitrinite reflectance and fluid inclusion microthermometry: a new calibration of old techniques. AAPG Bulletin, 84, 1647-1665.

Tornos F. \& Spiro B.F., 2000. The geology and isotope geochemistry of the talc deposits of Puebla de Lillo (Cantabrian Zone, Spain). Economic Geology, 95, 1277-1296.

Truyols J., Alvarez F., Arbizu M., García-Alcalde J.L., Garcýa-Lopez S., Martýnez-Chacon M.L., Mendez-Bedia I., Mendez-Fernandez C., Menendez J.R., Sanchez de Posada L.C., Soto F., Rodriguez-Fernandez L.R., \& Lobato L., 1984. Memoria explicativa de la Hoja del Mapa Geologico Nacional Espania. 1:50.000, num. 104, Bonar. 2a serie MAGNA. Instituto Geológico y Minero de España, Madrid, Espania.

Uysal T.I., Glikson M., Golding S.D. \& Audsley F., 2000. The thermal history of the Bowen Basin, Queensland, Australia: vitrinite reflectance and clay mineralogy of Late Permian coal measures. Tectonophysics, 323, 105-129.

Wagner R.H. \& Winkler Prins C.F., 1985. The Cantabrian and Barruelian stratotypes: a summary of basin development and biostratigraphic information. [in:] Lemos de Sousa M.J. \& Wagner R.H. (eds), Papers on the Carboniferous of the Iberian Peninsula, Anais da Facultade de Ciencias, Universidade do Porto, 64, 359-410.

Yalcin M.N., Littke R. \& Sachsenhoffer R.F., 1997. Thermal history of sedimentary basins. [in:] Welte D.H., Horsfield B. \& Baker D. (eds), Petroleum and basin evolution, Springer, 71-168.

Yamaji A., 1986. Analysis of vitrinite reflectance-burial depth relations in dynamical geological settings by direct integration method. Journal of Japan Association of Petroleum Technology, 51, 3, 1-8. 